\title{
Undetermined Sertoli Cell Tumor
}

National Cancer Institute

\section{Source}

National Cancer Institute. Undetermined Sertoli Cell Tumor. NCI Thesaurus. Code C98794.

An ovarian neoplasm comprising Sertoli cells in which the malignancy status has not been established. 